\title{
S-wave velocity in samples of calcareous waste
}

\author{
Elżbieta Pilecka ${ }^{1, *}$, Jakub Zięba ${ }^{1}$, and Rafał Pilecki ${ }^{2}$ \\ ${ }^{1}$ Cracow w University of Technology, Faculty of Civil Engineering, Krakow, Poland \\ ${ }^{2}$ Graduate from Cracow University of Technology, Faculty of Civil Engineering, Krakow, Poland
}

\begin{abstract}
The studies have been carried out in the calcareous waste area "White Seas" of the closed factory Solvay Sodium Plant in Krakow in southern Poland. The study was conducted to determine the S-wave velocity of samples of the anthropogenic subsoil. It was aimed at the possibility of using post-production waste for construction purposes. Due to the high humidity of the analysed samples, the tests were carried out on samples taken using Shelby type probes, from the $12 \mathrm{~m}$ borehole. The saturation level of soil samples was estimated based on Skempton's law (B>0.95). The Swave velocity was determined depending on the different degree of saturation as well as the different degree of consolidation of the soil sample. Only S-wave velocity was analysed because properties of samples caused difficulties in determining of the first arrivals of P-wave. The measurements were carried out in the triaxial apparatus equipped with Bender element (BE). Finally, the shear modulus $\mathrm{G}$ of the samples were calculated. Results showed the effect of S-wave velocity increase with increase of degree of saturation and with the increase of effective stress in tested samples. The Swave velocity significant increased up to about $100 \mathrm{kPa}$, and then this increase was smaller.
\end{abstract}

Keywords: Solvay plant, calcareous waste, bender element test, P- and S- wave velocity

\section{Introduction}

In recent years, numerous geotechnical studies have been carried out in the area of the factory Solvay Sodium Plant in Krakow (which is currently closed) [1-7]. The factory produced sodium carbonate $\left(\mathrm{Na}_{2} \mathrm{CO}_{3}\right)$ since 1906 . As a result of the production, the studied waste was produced [6]. This waste developed in the form of a slurry and it was entirely deposited in sedimentation tanks. These tanks occupied a total area of over 30 hectares. The stored waste formed heap of nearly 20 meters high. In the 1990s, on the basis of hydrogeological and hydrotechnical studies, the environmental effect of the waste from the Solvay Plants was analysed [8], and then the reclamation of this area was decided. The designated plan [9] and further development plans in this part of Krakow forced the necessity of analysing the soil substrate and evaluating its suitability for construction purposes. Currently, in the area of "White Seas" in Krakow two construction projects are realized. These are the construction of

\footnotetext{
*Corresponding author: epilecka@pk.edu.pl
} 
the Lagiewnicka Route by the enterprise "Trasa Lagiewnicka" [5] and the golf course implemented by the Golf \& Spa Resort company. In both cases, post-production waste, which, as an anthropogenic soil occurs in the foundation level, was a problem related to the choice of the type of construction of future buildings.

The study was aimed at the possibility of using post-production waste for construction purposes. In addition, the Soil - Structure Interaction Division, Cracow University of Technology, also participated in research with the aim of determining the load capacity of piles [4] for future buildings included in the John Paul II Centre.

Due to the lack of data related to the deformation parameters of calcareous waste from the Solvay Sodium Plant in Krakow, the Soil - Structure Interaction Division, Cracow University of Technology, conducted research to determine the dynamic shear modulus G of the subsoil samples from the area of "White Seas" [6,7]. Only dynamic shear modulus G was analysed because properties of samples caused difficulties in determining of the first arrivals of P-wave. The G modulus of the samples was calculated depending on the different degree of saturation as well as the different degree of consolidation of the soil sample. The tests were carried out on samples taken using Shelby type probes. In the study it was necessary to modify the probe to receive a sample with an undisturbed structure.

In the paper, a detailed modification of the sampler is presented. We also presented methodology of laboratory test and finally the results of the determination of the S-wave velocity and dynamic shear modulus $\mathrm{G}$ for the calcareous samples.

\section{Undisturbed samples}

In the study, for the P- and S- wave velocity determination by the laboratory method, the Shelby sampler was adapted to take samples with an undisturbed structure (Fig. 1).
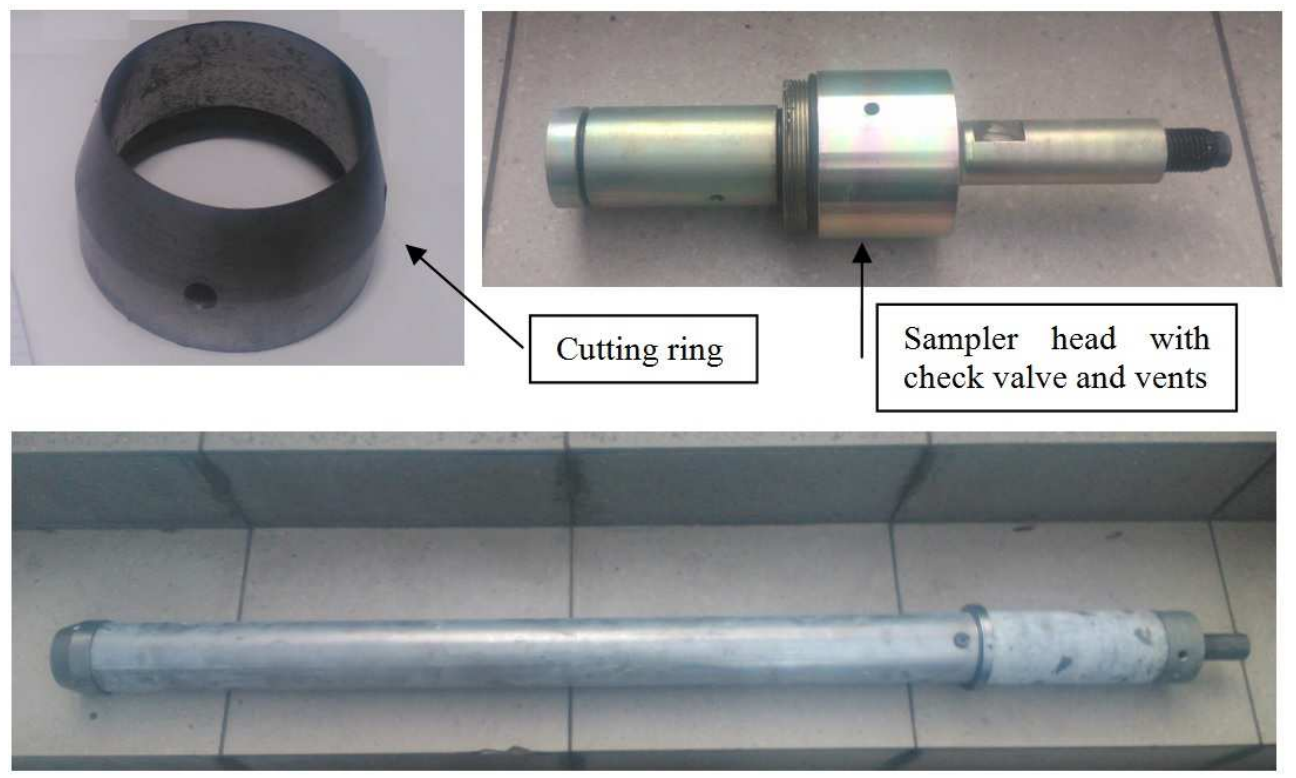

Fig. 1. Modified thin-wall open drive soil sampler. 
Due to the high humidity of the analysed samples, i.e. around $200 \%$, the soil exhibited large deformations even at low pressure. In addition, during the extrusion of the sample from the probe there was a significant consolidation of the soil sample and a significant loss of water from the tested soil. The possibility of receiving a sample with an undisturbed structure could therefore be achieved by matching the Shelby probe with a plastic insert, which could be cut in the laboratory as required.

Commercial solutions for probes with plastic inserts are mainly found for small diameters [10]. Finally, a probe with an exterior diameter of $80 \mathrm{~mm}$ was chosen, which allowed for the installation of a plastic pipe with a diameter of $75 \mathrm{~mm}$. Therefore, the interior diameter of the probe was $71 \mathrm{~mm}$. The consequence of increasing the thickness of the sampler wall, consisting of a steel pipe and a PE pipe, was to adjust the cutting knife to avoid large deformations of the sample taken. The last modification of the sampler was to provide the probe with a cylinder, so that during the extraction of the probe from the borehole in the sampler a vacuum was created. Due to this modification, the probability of receiving the sample remaining undisturbed has been significantly increased. All modifications of the probe are shown in figure 1.

The probe is terminated with a screw, and because of this, it is possible to push the Pagani static probe (CPT) to a specific depth. Due to the anchoring of the probe, it is possible to take samples from depths of up to $20 \mathrm{~m}$. In the case of smaller sampling depths, it is possible to use a lightweight dynamic probe or impact hammer to drive the sampling probe into subsoil.

\section{Materials and methodology}

Samples for laboratory tests were taken from a borehole drilled to the layer at a depth of approximately $8 \mathrm{~m}$ up to around $12 \mathrm{~m}$ with a high water content [4] (Fig. 2).

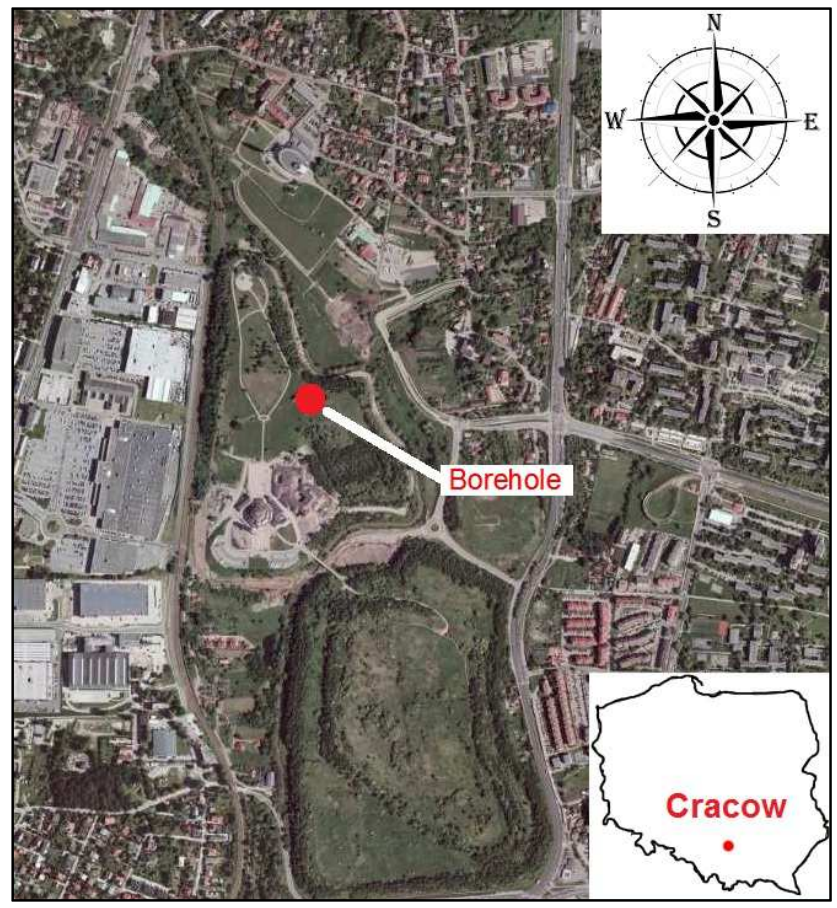

Fig. 2. The location of borehole on the research area of White seas. 
Eight samples (S1 - S8) with dimensions of 50mm in diameter and an initial height of $75 \mathrm{~mm}$ were cut from the probes discussed in chapter 2. The height before each test was determined individually [11]. The results of the particle size distribution and chemical composition of the tested samples did not differ from the samples taken from a depth of 1 to $5 \mathrm{~m}$, the results of which were previously presented by the authors [6]. The main element of the anthropogenic soil is calcium carbonate $\left(\mathrm{CaCO}_{3}\right)$, which occurs together with silicon oxides $\left(\mathrm{SiSO}_{2}\right)$ and other substances (i.e. $\mathrm{P}_{2} \mathrm{O}_{5}, \mathrm{CaSO}_{4}, \mathrm{MgSO}_{4}, \mathrm{BaSO}_{4}, \mathrm{NaCl}, \mathrm{CaCl}_{2}$ [1]).

All tests were carried out in accordance with the European Standard [12], which also has the status of the Polish standard. The average physical parameters of soil from at a depth 8$12 \mathrm{~m}$ are presented in table 1 . It was also possible to calculate the following initial soil parameters, which are presented in table 2 .

Tab. 1. The average physical parameters of the soil in the area of the "White Seas".

\begin{tabular}{|c|c|c|c|}
\hline $\begin{array}{c}\text { Sample } \\
\text { number }\end{array}$ & $\begin{array}{c}\text { Water content } \\
{[\%]}\end{array}$ & $\begin{array}{c}\text { Bulk density } \\
{\left[\mathbf{k g} / \mathbf{m}^{3}\right]}\end{array}$ & $\begin{array}{c}\text { Specific density } \\
{\left[\mathbf{k g} / \mathbf{m}^{3}\right]}\end{array}$ \\
\hline $\mathrm{S} 1 \div \mathrm{S} 8$ & 200 & 1210 & 2680 \\
\hline
\end{tabular}

Tab.2. The calculated avarage physical parameters of the soil in the area of the "White Seas".

\begin{tabular}{|c|c|c|c|c|}
\hline $\begin{array}{c}\text { Sample } \\
\text { number }\end{array}$ & $\begin{array}{c}\text { Dry mass density } \\
{[\mathbf{k g} / \mathbf{m} 3]}\end{array}$ & Porosity [-] & $\begin{array}{c}\text { Total water } \\
\text { content }[\%]\end{array}$ & $\begin{array}{c}\text { Degree of } \\
\text { saturation } \\
{[-]}\end{array}$ \\
\hline $\mathrm{S} 1 \div \mathrm{S} 8$ & 400 & 0.85 & 210.5 & 0.95 \\
\hline
\end{tabular}

The tests of determination of the P- and S-wave velocity were carried out using the VJTech triaxial compression apparatus equipped with Bender element. The length of the piezo elements, i.e. the transmitter and receiver, is $6 \mathrm{~mm}$ in total.

Shirley and Anderson [13] introduced bender ceramics in place of the shear plates for testing dry sand. Incorporation of bender elements in triaxial apparatus is arguably the most common practice, as demonstrated by Chan et al. [14].

The tests to determine the wave velocity were carried out for the following eight sample states:

- for undisturbed structure sample (sample S1),

- for samples fully saturated (sample S2),

- for samples fully saturated and then isotropically consolidated with the values of the effective stress being 50, 100, 150, 200, 250, 300kPa (samples S3 - S8).

All tests were performed using a sinusoidal wave, generated with time intervals of 15 seconds. This time was determined on the basis of the total time of signal suppression and the time necessary for registering the reply. The registered signal was filtered into a continuous function to better evaluate wave transition time. For this purpose, a moving average method was used with an eight-point window. For each sample, twenty designations were made on the basis of which the result was averaged. Filtering were performed in order to obtain the exact time of P- and S-wave arrivals.

By using the "back pressure" method [15] it was possible to fully saturate soil samples using a triaxial compression test apparatus. "Back pressure" was applied to the top of the sample. It is possible to determine the saturation level of a sample in the form of calculated Skempton parameter B:

$$
B=\frac{\Delta \delta_{1}}{\Delta \delta_{3}}
$$


where:

$\Delta \delta_{1}$ - change in pressure value in the triaxial cell [kPa],

$\Delta \delta_{3}$ - change in pressure in the soil sample [kPa].

Then a consolidation step was carried out by varying the pressure difference in the cell and in the sample. Six levels of consolidation were used, i.e. 50, 100, 150, 200, 250 and $300 \mathrm{kPa}$. At each state of the sample, the determination of the P- and S-wave velocity was carried out. Finally, only S-wave velocity was analysed because properties of samples caused difficulties in determining of the P-wave first arrivals (Fig. 3).

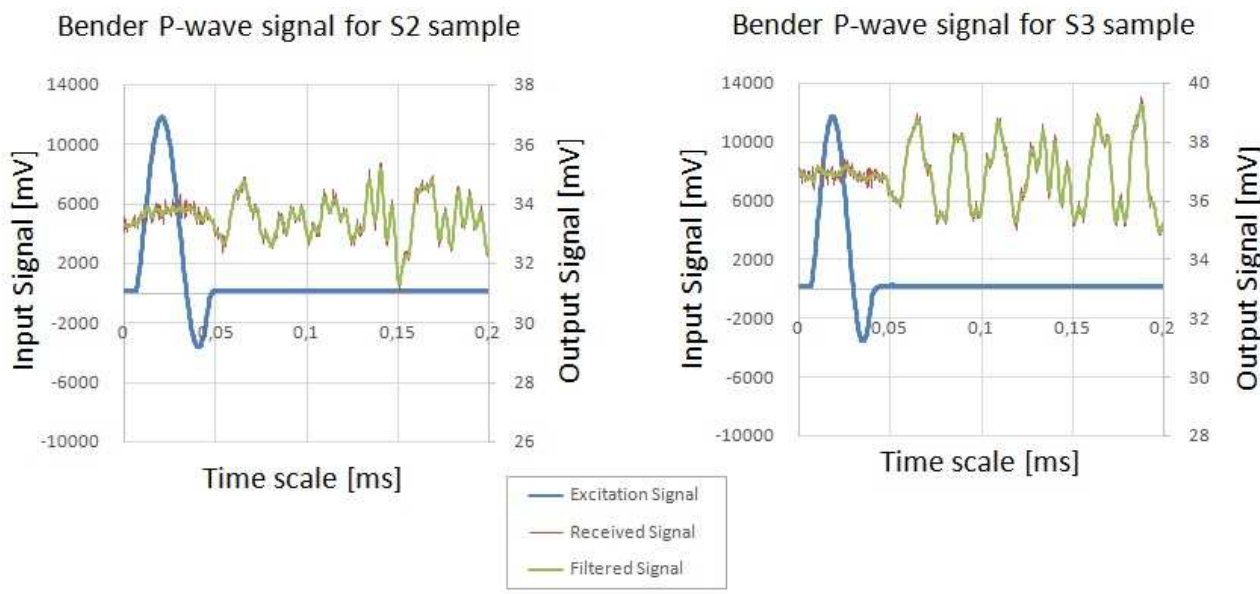

Fig. 3. The P-wave excitation and received signal for $\mathrm{S} 2$ and $\mathrm{S} 3$ sample.

In the study, an additional element the Local Strain Transducers LVDT (linear variable differential transformer) was applied which provided small strain measurements of axial and radial strain Fig. 4). Due to the use of sensors that were mounted directly on the ground sample, it was possible to control the change in sample height at each stage of the triaxial test $[16,17]$. The sensitivity of the LVDT displacement transducers was $0.001 \mathrm{~mm}$ and the measuring range of LVDT was $50 \mathrm{~mm}$.

The advantage of the small deformation sensors used was the precise determination of the height changes and then time of the wave propagation from the transmitter to the receiver.

\section{Results and analysis}

The waveforms of the input and output signal for S-wave are shown in figure 5 . The S-wave velocity changes from $49.9 \mathrm{~m} / \mathrm{s}$ for sample in undisturbed structure up to $86.9 \mathrm{~m} / \mathrm{s}$ in fully saturated conditions. In conditions of effective stress increase, $\mathrm{S}$-wave velocity increases from $94.1 \mathrm{~m} / \mathrm{s}$ for $50 \mathrm{kPa}$ to 168.2 for $300 \mathrm{kPa}$ of fully saturated samples.

The results of the $\mathrm{S}$-wave velocities for eight sample states are presented in table 3. 


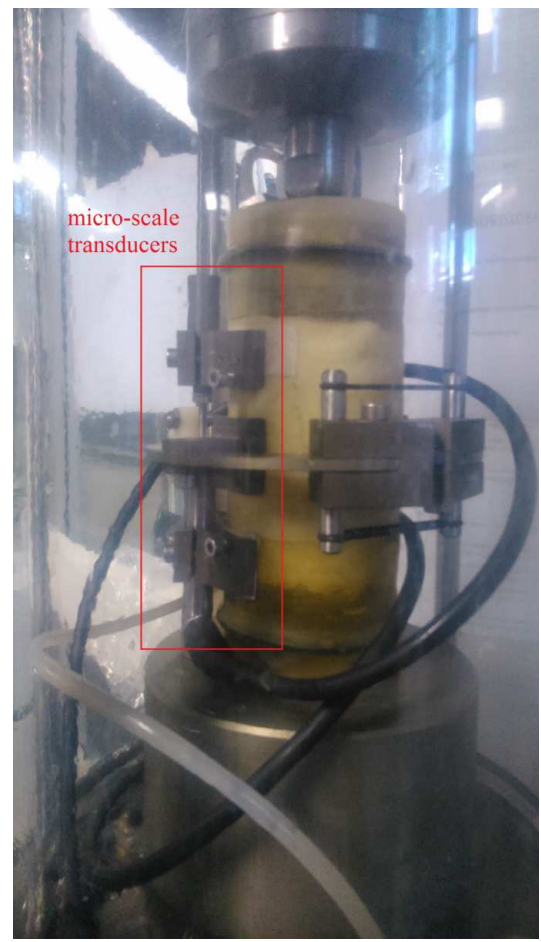

Fig. 4. A calcareous waste sample in the triaxial cell equipped with micro-scale transducers.

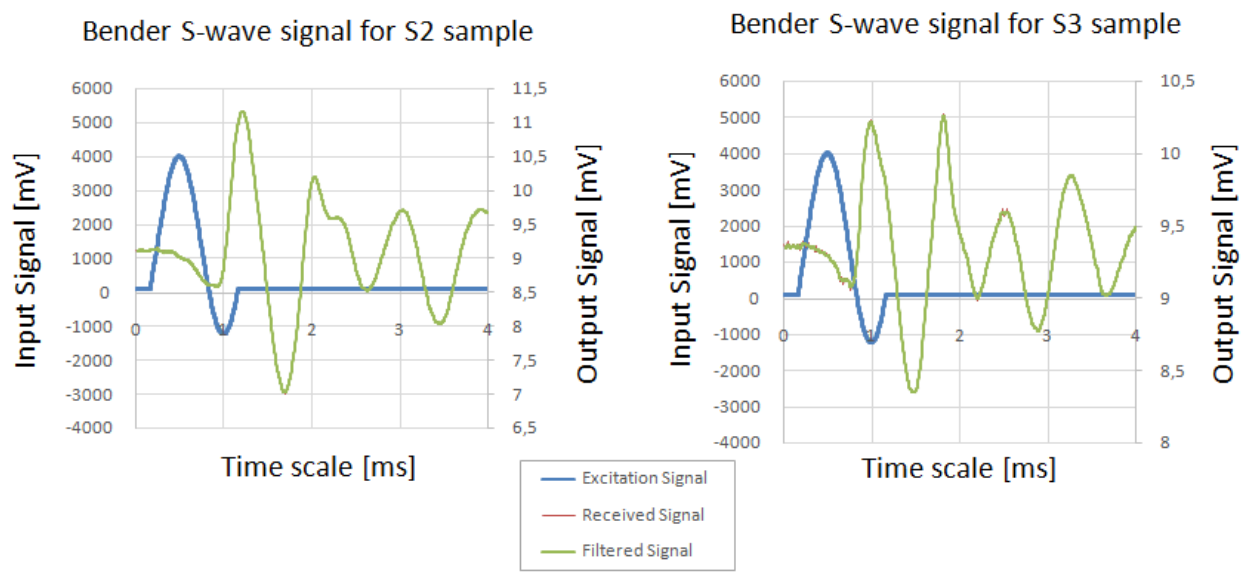

Fig. 5. The S-wave excitation and received signal for S2 and S3 sample. (Red line coincides with green line).

Tab. 3. The average values of the parameters of the tested samples for the S-wave test.

\begin{tabular}{|c|c|c|c|c|c|c|c|c|}
\hline & \multirow{2}{*}{$\begin{array}{c}\text { Sample } \\
\text { States }\end{array}$} & $\begin{array}{c}\text { Undisturbed } \\
\text { structure } \\
\text { (S1) }\end{array}$ & \multirow{2}{*}{$\begin{array}{c}\text { Fully } \\
\text { saturated } \\
(\mathrm{S} 2)\end{array}$} & \multicolumn{6}{|c|}{$\begin{array}{c}\text { Effective stress in consolidation [kPa] } \\
\text { (fully saturated) }\end{array}$} \\
\cline { 5 - 10 } & & $\begin{array}{c}50 \\
(\mathrm{~S} 3)\end{array}$ & $\begin{array}{c}100 \\
(\mathrm{~S} 4)\end{array}$ & $\begin{array}{c}150 \\
(\mathrm{~S} 5)\end{array}$ & $\begin{array}{c}200 \\
\text { (S6) }\end{array}$ & $\begin{array}{c}250 \\
\text { (S7) }\end{array}$ & $\begin{array}{c}300 \\
(\mathrm{~S} 8)\end{array}$ \\
\hline $\begin{array}{c}\text { S-wave } \\
\text { velocity } \\
{[\mathrm{m} / \mathrm{s}]}\end{array}$ & 49.9 & 86.9 & 94.1 & 132.9 & 142.0 & 154.8 & 151.9 & 168.2 \\
\hline
\end{tabular}


As a result of analysing the wave velocity, it may be noticed that with the increase of effective stress in tested samples the S-wave velocity increases according to figure 6 . The Swave velocity significant increases up to about $100 \mathrm{kPa}$, and then this increase is smaller.

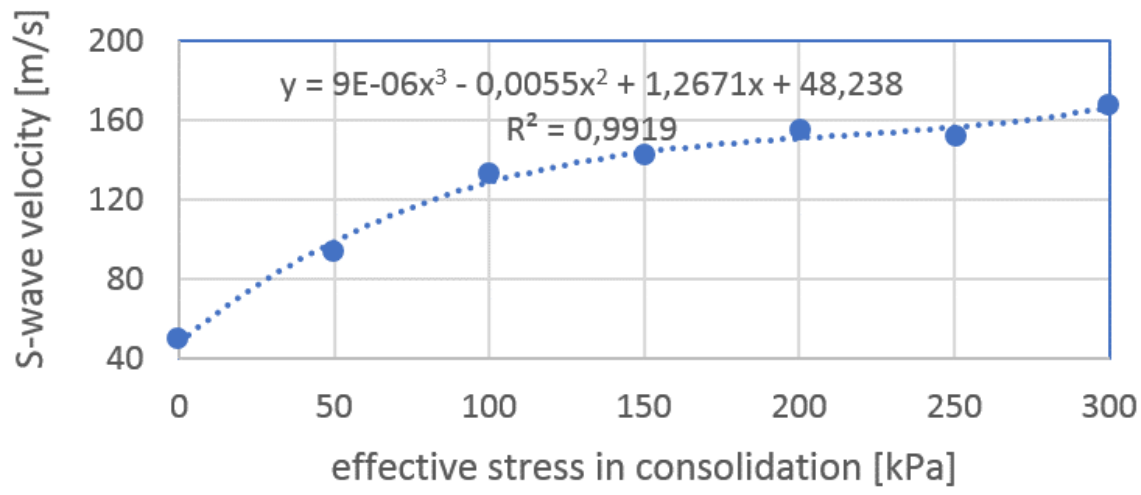

Fig. 6. S-wave velocity to effective stress in calcareous waste samples.

In addition, the measurements of deformation of the sample with LVDT sensors allowed for the determination of changes in the volume of the sample. In effect, it was possible to precisely determine the changes in the porosity of the tested sample. It is necessary to note the very large outflow of water at the consolidation stage. Volumetric distortions registered during the test for $50 \mathrm{kPa}$ amounted to about $18.6 \%$, while for the $300 \mathrm{kPa}$ test, volumetric strains reached a water pressure of above $32.8 \%$ at the time of full dissipation. Finally, the calculated dynamic $\mathrm{G}$ modulus was presented in table 4.

Tab. 4. The average values of the dynamic shear modulus $\mathrm{G}$ of the soil calcareous waste samples.

\begin{tabular}{|c|c|c|c|c|c|c|c|c|}
\hline \multirow{2}{*}{$\begin{array}{c}\text { Sample } \\
\text { states }\end{array}$} & \multirow{2}{*}{$\begin{array}{c}\text { Undisturbed } \\
\text { structure } \\
(\mathrm{S} 1)\end{array}$} & \multirow{2}{*}{$\begin{array}{c}\text { Fully } \\
\text { saturated } \\
(\mathrm{S} 2)\end{array}$} & \multicolumn{6}{|c|}{$\begin{array}{c}\text { Effective stress in consolidation [kPa] } \\
\text { (fully saturated) }\end{array}$} \\
\cline { 5 - 10 } & & $\begin{array}{c}50 \\
(\mathrm{~S} 3)\end{array}$ & $\begin{array}{c}100 \\
(\mathrm{~S} 4)\end{array}$ & $\begin{array}{c}150 \\
(\mathrm{~S} 5)\end{array}$ & $\begin{array}{c}200 \\
\text { (S6) }\end{array}$ & $\begin{array}{c}250 \\
(\mathrm{~S} 7)\end{array}$ & $\begin{array}{c}300 \\
\text { (S8) }\end{array}$ \\
\hline $\begin{array}{c}\text { Dynamic } \\
\text { modulus G } \\
{[\mathrm{MPa}]}\end{array}$ & 2.92 & 9.07 & 10.63 & 21.19 & 24.21 & 27.69 & 28.76 & 33.94 \\
\hline
\end{tabular}

\section{Conclusions}

The study presents the results of the determination of S-wave velocity and dynamic Gmodulus conducted by the Soil - Structure Interaction Division, Cracow University of Technology in the area of " White Seas " in Krakow. The samples taken represented a subsoil of post-production waste of the Solvay Sodium Plant. The S-wave velocity of the samples was measured depending on the different degree of saturation as well as the consolidation of the soil sample. Using the triaxial apparatus, due to which the wave velocity was determined in the saturated and consolidated medium, it was possible to calculate the dynamic modulus.

In general, we may observe the effect of S-wave velocity increase with increase of degree of saturation of the tested samples. It may be noticed that with the increase of effective stress in tested samples the S-wave velocity significant increases up to about $100 \mathrm{kPa}$, and then this increase is smaller. The same effect was observed with modulus $\mathrm{G}$ changes. 


\section{References}

1. I. Krzak, Zagospodarowanie terenów poprzemystowych Krakowskich Zakładów Sodowych ,Solvay” (Post - industry reclamation of Cracow Soda Industry „Solvay”), Problemy Ekologii Krajobrazu, 17, 283-287 (2005) (in Polish)

2. B. Czado, Analiza nośności pali fundamentowych na podstawie polowych badań gruntów sonda statyczna (Analysis of bearing capacity of foundation piles based on field cone penetration tests results), Rozprawa doktorska, Biblioteka Politechniki Krakowskiej (2014) (in Polish)

3. M. Gliniak, M. Pawul, W. Sobczyk, Wptyw transportu i sktadowisk poprzemystowych byłych Krakowskich Zakładów Sodowych ,, Solvay” na stan i jakość wody rzeki Wilga w Krakowie (Impact of the transport and postindustrial landfills of Cracow Soda Works "Solvay" on the status and quality of water in Wilga River in Krakow), Logistyka 4, 4295-4302 (2014) (in Polish)

4. B. Wrana, Pile load capacity - calculation methods, Studia Geotechnica et Mechanica 37 (4), 83-93 (2015) doi: 10.1515/sgem-2015-0048

5. http://www.trasalagiewnicka.krakow.pl/

6. E. Pilecka, J. Zięba, E3S Web Conf. 24, 02006 (2017) doi: 10.1051/e3sconf/20172402006

7. J. Zięba, M. Bazarnik, E3S Web Conf. 36, 03006 (2018) doi: $10.1051 / \mathrm{e} 3$ sconf $/ 20183603006$

8. A. Ślęzak, Wptyw składowiska odpadów Krakowskich Zakładów Sodowych na wody (The impact of the Krakowskie Zaktady Sodowe waste landfill on water), Przewodnik III Konferencji Sozologicznej PTG. Wyd. AGH, Kraków (1993) (In Polish)

9. Biuro Rozwoju Krakowa, Miejscowy plan zagospodarowania przestrzennego terenów Krakowskich Zakładów Sodowych ,Solvay” w likwidacji, w rejonie ulic: Zakopiańskiej, Myślenickiej i Podmoktej (The local development plan for the areas of the Krakow Soda Plant "Solvay" in liquidation, in the area of: Zakopiańska, Myślenicka and Podmokła Streets), Kraków (1994) (In Polish)

10. http://www.szkurlat.pl/

11. B. Wrana, Laboratory testing of soil mechanics, Cracow University of Technology Publishing House (2015)

12. EN ISO 17892-1,2,3:2014 Geotechnical investigation and testing - Laboratory testing of soil - Part1, 2, 3

13. Shirley DJ, Anderson AL, Acoustical and engineering properties of sediments, Report no. ARL-TR-75-58, applied research laboratories. University of Texas, Austin (1975)

14. Chan KH, Boonyatee T, Mitachi T Effect of bender element installation in clay samples. Ge' otechnique 60(4), 287-291 (2010) doi: 10.1680/geot.7.00135

15. Black, D.K. and K.L. Lee., Saturating laboratory samples by back pressure, J. Soil Mech. \& Found. Division, ASCE. 99, 75-93 (1973)

16. T. Cuccovillo, M.R. Coop, The measurement of local axial strains in triaxial tests using LVDTs, Geotechnique 47 (1), 167-171 (1997) doi: 10.1680/geot.1997.47.1.167

17. G. Da Re, M.C. Santagata, J.T. Germaine, LVDT Based System for the Measurement of the Prefailure Behavior of Geomaterials, Geotechnical Testing Journal 24 (3), 288-298 (2001) doi: 10.1520/GTJ11347J 